\title{
Pengaruh Pemberian Tuntunan Penyelesaian Latihan Soal Dalam Pembelajaran Langsung Terhadap Pemahaman Konsep Perhitungan pH Larutan Penyangga Asam Pada Siswa Kelas XI MIPA MAN Kota Palangka Raya Tahun Ajaran 2018/2019
}

\author{
Asmy Dyah Hayunanda ${ }^{1 *}$, Abudarin ${ }^{1}$, Karelius $^{2}$ \\ ${ }^{1}$ Program Studi Pendidikan Kimia, Universitas Palangka Raya, Indonesia \\ ${ }^{2}$ Program Studi Kimia, Universitas Palangka Raya, Indonesia \\ *Email: hayunandaasmy27@gmail.com
}

\begin{abstract}
Abstrak
Banyak siswa mengalami kesulitan dalam menyelesaikan soal-soal perhitungan larutan penyangga. Tujuan penelitian ini adalah untuk menjelaskan pengaruh pemberian tuntunan penyelesaian latihan soal dalam pembelajaran langsung terhadap pemahaman konsep perhitungan $\mathrm{pH}$ larutan penyangga asam pada siswa kelas XI MIPA MAN Kota Palangka Raya tahun ajaran 2018/2019. Penelitian ini merupakan penelitian kuantitatif dengan rancangan eksperimen pretest-posttest control group design. Sampel penelitian adalah 69 siswa kelas XI MIPA MAN Kota Palangka Raya tahun ajaran 2018/2019. Instrumen yang digunakan untuk mengukur pemahamn konsep adalah tes pemahaman konsep (tes I dan tes II) berbentuk uraian objektif berjumlah 3 soal. Hasil uji statistik menggunakan uji-t menunjukkan bahwa thitung $(5,383)$ lebih besar dari ttabel $(1,67)$ pada taraf signifikan $5 \%$, artinya pemberian tuntunan penyelesaian latihan soal berpengaruh terhadap pemahaman konsep perhitungan $\mathrm{pH}$ larutan penyangga asam pada siswa kelas XI MIPA MAN Kota Palangka Raya tahun ajaran 2018/2019. Rata-rata nilai tes II kelas eksperimen $(77,992)$ lebih tinggi dari kelas kontrol $(60,561)$.
\end{abstract}

Kata Kunci: larutan penyangga asam, tuntunan penyelesaian soal. 


\section{Pendahuluan}

Kimia merupakan salah satu cabang ilmu yang dihasilkan dari IPA di samping matematika, biologi dan fisika. Kimia merupakan mata pelajaran yang memiliki karakteristik tersendiri dan keterampilan dalam memecahkan masalah masalah yang berupa fakta, konsep, hukum dan teori yang berhubungan dengan komposisi, sifat dan perubahan energi. Ilmu ini diperoleh dan disusun berdasarkan proses ilmiah yang dilakukan dengan melakukan pengamatan, pengukuran, analisis dan pengambilan keputusan (Simatupang, 2017).

Salah satu pokok bahasan yang dipelajari siswa SMA kelas XI adalah konsep perhitungan kimia, salah satunya adalah perhitungan $\mathrm{pH}$ larutan penyangga. Perhitungan $\mathrm{pH}$ larutan penyangga dipelajari tidak hanya sekedar membaca, akan tetapi juga memerlukan pemahaman yang baik untuk dapat menganalisis lebih lanjut. Proses analisis lebih lanjut diperlukan untuk memperbaiki hasil pemahaman konsep awal siswa.

Penelitian yang dilakukan oleh Aini (2013), menunjukkan bahwa siswa mengalami kesulitan dalam menyelesaikan soal-soal perhitungan larutan penyangga. Diketahui sebanyak $66,83 \%$ pemahaman konsep siswa tentang larutan penyangga masih tergolong rendah dan mengalami kesulitan pada penyelesaian persamaan reaksi dan perhitungan tentang larutan penyangga. Hal ini disebabkan sebagian besar siswa kesulitan dalam menentukan jumlah mol sisa reaksi karena tidak mampu menuliskan reaksi, menentukan komponen larutan penyangga dan bahkan tidak mengetahui sifat-sifat larutan asam-basa.

Kesulitan siswa dalam menghitung $\mathrm{pH}$ larutan penyangga asam adalah mengabaikan salah satu jumlah mol sisa dan tidak menggunakan rumus yang 
seharusnya. Rumus yang digunakan siswa adalah rumus asam kuat, dimana akhirnya siswa mengabaikan Ka yang diketahui di dalam soal. Hal inilah yang menyebabkan siswa mengalami kesulitan.

Perhitungan larutan penyangga termasuk dalam jenis pengetahuan prosedural, dimana cara belajar yang sesuai dalam mengatasi kesulitan yang dialami siswa adalah dengan banyak mengerjakan latihan soal. Penggunaan tuntunan penyelesaian dalam latihan soal dimaksudkan untuk memperlancar kegiatan belajar mengajar sehingga dapat memperbesar daya serap siswa terhadap materi. Selain itu, tuntunan digunakan untuk memperjelas penyajian pesan dan informasi sehingga dapat meningkatkan hasil belajar, dan meningkatkan serta mengarahkan perhatian siswa. Penggunaan tuntunan penyelesaian akan menjadikan siswa lebih termotivasi untuk belajar dan dapat meningkatkan pemahaman konsep siswa dalam menyelesaikan perhitungan $\mathrm{pH}$ larutan penyangga.

Berdasarkan uraian di atas, perlu adanya kajian mengenai pengaruh pemberian tuntunan penyelesaian latihan soal dalam pembelajaran langsung terhadap pemahaman konsep perhitungan $\mathrm{pH}$ larutan penyangga asam pada siswa kelas XI MIPA MAN Kota Palangka Raya tahun ajaran 2018/2019.

Tujuan penelitian ini adalah untuk menjelaskan pengaruh pemberian tuntunan penyelesaian latihan soal dalam pembelajaran langsung terhadap pemahaman konsep perhitungan $\mathrm{pH}$ larutan penyangga asam pada siswa kelas XI MIPA MAN Kota Palangka Raya tahun ajaran 2018/2019. 


\section{Metodologi Penelitian}

Penelitian ini termasuk dalam penelitian kuantitatif dengan rancangan eksperimen pretest-posttest control group design. Peneliti melakukan suatu percobaan dengan memberikan perlakuan dan membandingkan pengaruh dari perlakuan yang diberikan pada suatu sampel. Peneliti memanfaatkan dua kelas untuk dijadikan sampel penelitian, kelas pertama merupakan kelas eksperimen yang diberi latihan soal dengan tuntunan penyelesaian dan kelas kedua merupakan kelas kontrol yang diberi latihan soal tanpa tuntunan penyelesaian. Selanjutnya, hasil akhir dari kedua sampel dibandingkan. Berikut desain eksperimen pretest posttest control group design, yang digambarkan dengan Tabel 1.

Tabel 1. Desain Pembelajaran

\begin{tabular}{lcccc}
\hline Kelompok & Pembelajaran & Tes I & Perlakuan & Tes II \\
\hline Eksperimen $(\mathrm{E})$ & $\mathrm{P}_{1}$ & $\mathrm{X}_{\mathrm{e}}$ & $\mathrm{A}_{\mathrm{e}}$ & $\mathrm{Y}_{\mathrm{e}}$ \\
Kontrol $(\mathrm{K})$ & $\mathrm{P}_{1}$ & $\mathrm{X}_{\mathrm{k}}$ & - & $\mathrm{Y}_{\mathrm{k}}$ \\
\hline Keterangan: & & & & \\
$\mathrm{P}_{1}=$ pembelajaran langsung & & & \\
$\mathrm{X}_{\mathrm{e}}=$ tes kemampuan awal kelas eksperimen & & \\
$\mathrm{X}_{\mathrm{k}}=$ tes kemampuan awal kelas kontrol & & \\
$\mathrm{A}_{\mathrm{e}}=$ pembelajaran langsung dilanjutkan latihan soal & \\
$\mathrm{Y}_{\mathrm{e}}=$ tes II kelas eksperimen & & \\
$\mathrm{Y}_{\mathrm{k}}=$ tes II kelas kontrol
\end{tabular}

Teknik pengambilan sampel pada penelitian ini menggunakan penarikan sampel acak bergerombol (clustered random sampling) yang mengacu pada satu kelompok (kelas) bukan secara individu. Sampel pada penelitian ini secara acak 
diambil dua kelas sebagai kelas kontrol dan kelas eksperimen. Untuk memperoleh data penelitian, instrumen yang digunakan meliputi:

1. Tes pemahaman konsep (tes I dan tes II). Instrumen yang digunakan dalam penelitian ini berupa uraian objektif berjumlah 3 soal untuk mengetahui pemahaman konsep siswa terhadap materi perhitungan $\mathrm{pH}$ larutan penyangga. Tes I dan tes II merupakan soal yang berbeda, dengan bobot yang sama.

2. Latihan soal dengan tuntunan penyelesaian pada penelitian ini dikemas dalam bentuk lembar kerja yang memuat soal berisi langkah-langkah penyelesaian soal yang diberikan untuk mempermudah siswa dalam mengerjakan soal.

Data yang diperlukan dalam penelitian ini adalah data kuantitatif, berupa skor hasil tes belajar siswa kelas XI MIPA semester II MAN Kota Palangka Raya tahun ajaran 2018/2019 dalam menyelesaikan soal konsep perhitungan pH larutan penyangga asam.

Teknik pengumpulan data yang digunakan dalam penelitian ini berupa tes uraian objektif. Adapun tahap-tahap yang digunakan dalam pengumpulan dan pengolahan data adalah sebagai berikut:

a. Tahap I, pada tahap ini kedua sampel (kelas kontrol dan kelas eksperimen) diberikan materi larutan penyangga asam dengan metode pembelajaran langsung. Selanjutnya, diberikan tes I untuk mengetahui dan mengukur kemampuan awal siswa terhadap materi pelajaran yang akan diberikan pada saat perlakuan. Hasil prasyarat kemudian dibandingkan dengan melihat skor rerata kelas. Bentuk tes berupa soal uraian objektif yang disusun oleh peneliti dengan adanya konsultasi terlebih dahulu dengan pihak yang bersangkutan, yakni dosen dan guru. 
b. Tahap II. Pada tahap ini, kelas yang berperan sebagai kelas eksperimen diberikan latihan soal dengan tuntunan penyelesaian saat proses pembelajaran. Sementara kelas kontrol diberikan latihan soal tanpa tuntunan cara mengerjakan. Baik kelas eksperimen maupun kelas kontrol sama-sama menggunakan metode pembelajaran langsung. Selain itu, juga diberikan materi dan jumlah jam belajar yang sama.

c. Tahap III. Tahap terakhir ini merupakan tahap pengukuran penguasaan materi siswa. Pengukuran ini diberikan dengan pemberian tes II pada masing-masing kelas. Data yang diperoleh kemudian dianalisis dengan teknik analisis data pada penelitian ini.

Data tes I didapat sebelum diberikan perlakuan, yakni pemberian latihan soal dengan tuntunan penyelesaian. Setelah diberikan perlakuan, data tes II baru dapat diambil. Selanjutnya, data dapat dianalisis untuk mengetahui ada dan tidaknya perubahan pemahaman konsep siswa setelah pembelajaran langsung yang dilanjutkan dengan latihan soal dengan tuntunan penyelesaian pada kelas eksperimen dan pembelajaran langsung dilanjutkan dengan latihan soal tanpa tuntunan penyelesaian pada kelas kontrol.

Pemeriksaan hasil tes tiap siswa dilakukan dengan memberi skor pada lembar jawaban. Langkah selanjutnya adalah dengan menjumlahkan skor yang diperoleh oleh masing-masing siswa dan mengkonversikan dalam bentuk nilai dengan rumus berikut:

$$
\text { Nilai }=\frac{\text { jumlah skor yang diperoleh siswa }}{\text { jumlah skor maksimal }} \times 100 \%
$$

Dilakukan uji prasyarat analisis dengan asumsi bahwa data tes I harus berdistribusi normal. Adapun uji normalitas dalam penelitian ini dilakukan untuk 
menguji normal tidaknya sebaran data kemampuan awal yang akan dianalisis. Rumus chi kuadrat, adalah:

$$
\boldsymbol{X}^{2}=\sum \frac{\left(f_{o}-f_{h}\right)^{2}}{f_{h}}
$$

Keterangan:

$\boldsymbol{X}^{2}=$ nilai chi kuadrat

$\mathrm{f}_{\mathrm{o}}=$ frekuensi observasi (hasil observasi)

$\mathrm{f}_{\mathrm{h}}=$ frekuensi harapan

Uji homogenitas data tes I dalam penelitian ini dilakukan untuk mengetahui homogen atau tidaknya varian kedua sampel. Uji homogenitas dilakukan dengan uji F, rumusnya sebagai berikut:

$$
\mathrm{F}=\frac{\text { varian terbesar }}{\text { varian terkecil }}
$$

Hipotesis adalah jawaban sementara terhadap rumusan masalah penelitian. Terdapat dua macam hipotesis penelitian yaitu hipotesis kerja $\left(\mathrm{H}_{\mathrm{a}}\right)$ dan hipotesis $\operatorname{nol}\left(\mathrm{H}_{0}\right)$.

$\mathrm{H}_{0}=$ pemberian tuntunan penyelesaian latihan soal dalam pembelajaran langsung tidak berpengaruh terhadap pemahaman konsep perhitungan $\mathrm{pH}$ larutan penyangga pada siswa kelas XI MIPA MAN Kota Palangka Raya tahun ajaran 2018/2019

$\mathrm{H}_{\mathrm{a}}=$ pemberian tuntunan penyelesaian latihan soal dalam pembelajaran langsung berpengaruh terhadap pemahaman konsep perhitungan $\mathrm{pH}$ larutan penyangga pada siswa kelas XI MIPA MAN Kota Palangka Raya tahun ajaran 2018/2019

$\mathrm{H}_{0}: \mu_{1} \leq \mu_{2}$

$\mathrm{Ha}: \mu_{1}>\mu_{2}$ 
Keterangan:

$\mu_{1}=$ hasil belajar pemberian tuntunan penyelesaian latihan soal dalam pembelajaran langsung (kelas eksperimen)

$\mu_{2}=$ hasil belajar tanpa pemberian tuntunan penyelesaian latihan soal dalam pembelajaran langsung (kelas kontrol)

Untuk menguji hipotesis tersebut digunakan uji-t dengan rumus berikut:

$$
\mathrm{t}=\frac{\bar{X}_{e}-\bar{X}_{k}}{\sqrt{\frac{\left(n_{e}-1\right) s_{e}^{2}+\left(n_{k}-1\right) s_{k}^{2}}{n_{e}+n_{k}-2}\left(\frac{1}{n_{k}}+\frac{1}{n_{e}}\right)}}
$$

\section{Keterangan:}

$\mathrm{t} \quad=$ signifikan koefisien

$\bar{X}_{\mathrm{e}} \quad=$ rata-rata kelas eksperimen

$\bar{X}_{\mathrm{k}} \quad=$ rata-rata kelas kontrol

$\mathrm{n}_{\mathrm{e}} \quad=$ jumlah sampel dari kelas eksperimen

$\mathrm{n}_{\mathrm{k}} \quad=$ jumlah sampel dari kelas kontrol

$\mathrm{s}_{\mathrm{e}} \quad=$ simpangan baku kelas eksperimen

$\mathrm{S}_{\mathrm{k}} \quad=$ simpangan baku kelas kontrol

\section{Hasil Penelitian Dan Pembahasan}

Hal yang paling penting dalam pelaksanaan pembelajaran adalah terlebih dahulu dilakukannya simulasi. Simulasi pembelajaran dilakukan di kelas XI MIPA MAN Kota Palangka Raya. Kelas yang dijadikan subjek simulasi adalah 
kelas XI MIPA 2 sebagai kelas eksperimen dan kelas XI MIPA 4 sebagai kelas kontrol. Simulasi berlangsung selama 2 kali pertemuan tiap kelas.

Pengambilan data dilakukan terhadap siswa kelas XI MIPA MAN Kota Palangka Raya pada semester genap tahun ajaran 2018/2019. Penelitian terbagi menjadi dua kelas, 35 orang siswa dari kelas XI MIPA 1 sebagai kelas eksperimen dan 34 orang siswa kelas XI MIPA 5 sebagai kelas kontrol. Kelas eksperimen diberi perlakuan dengan pembelajaran langsung menggunakan latihan soal dengan tuntunan penyelesaian dan kelas kontrol diberi perlakuan dengan pembelajaran langsung menggunakan latihan soal tanpa tuntunan penyelesaian.

Deskripsi data pemahaman konsep siswa terdiri dari tes I dan tes II. Data nilai tes digunakan untuk mengetahui hasil perlakuan yang diberikan, dengan dilakukannya uji N-gain. Selain itu juga digunakan untuk mengetahui pengaruh penggunaan latihan soal dengan tuntunan penyelesaian terhadap pemahaman siswa. Pelaksanaan tes I dan tes II dilakukan dengan waktu yang sama dengan jumlah masing-masing tes berisi 3 butir soal uraian objektif.

Setelah pembelajaran langsung, didapatkan data rata-rata tes I kelas eksperimen sebesar 21,688 dan setelah diberikan latihan soal dengan tuntunan penyelesaian, didapatkan data rata-rata tes II sebesar 77,992. Hal ini menunjukkan peningkatan rata-rata siswa sebesar 56,304. Nilai tes I pada kelas eksperimen memiliki nilai terendah 9,901 dan memiliki nilai tertinggi 36,364, serta nilai standar deviasi sebesar 6,047. Nilai tes II pada kelas eksperimen memiliki nilai terendah 59,091 dan memiliki nilai tertinggi 100, serta nilai standar deviasi sebesar 11,570. 
Setelah pembelajaran langsung, didapatkan data rata-rata tes I kelas kontrol sebesar 21,524 dan setelah diberikan latihan soal tanpa tuntunan penyelesaian, didapatkan data rata-rata tes II sebesar 60,561. Hal ini menunjukkan peningkatan rata-rata siswa sebesar 29,918. Nilai tes I pada kelas kontrol memiliki nilai terendah 13,636 dan memiliki nilai tertinggi 36,364, serta nilai standar deviasi sebesar 6,554. Nilai tes II pada kelas kontrol memiliki nilai terendah 27,273 dan memiliki nilai tertinggi 81,818 , serta nilai standar deviasi sebesar 14,318 .

Berdasarkan informasi yang sudah disampaikan oleh guru mata pelajaran kimia MAN Kota Palangka Raya dan rata-rata hasil ulangan tengah semester, sebelum dilakukan pengambilan data diketahui bahwa kemampuan yang dimiliki oleh kelas eksperimen dan kelas kontrol tidak jauh berbeda. Hal ini terbukti dengan hasil perhitungan uji normalitas dan homogenitas data tes I pada kedua kelas sampel.

Dilakukan uji prasyarat analisis dengan asumsi bahwa data tes I harus berdistribusi normal. Rangkuman prasyarat uji analisis data, sebagai berikut:

Tabel 2. Rangkuman Uji Normalitas Data Tes I

\begin{tabular}{|c|c|c|c|c|c|}
\hline Data Tes I & $\mathbf{N}$ & $\alpha$ & $x^{2}$ hitung & $x^{2}$ tabel & Kesimpulan \\
\hline $\begin{array}{c}\text { Eksperimen } \\
\text { Kontrol }\end{array}$ & $\begin{array}{l}35 \\
34\end{array}$ & 0,05 & $\begin{array}{c}10 \\
6,348\end{array}$ & 11,07 & Normal \\
\hline Keterangan: I & um & iswa & & & \\
\hline
\end{tabular}


Tabel 3. Rangkuman Uji Homogenitas Data Tes I

\begin{tabular}{ccccc}
\hline Data Tes I & Varians & $\mathbf{F}_{\text {hitung }}$ & $\mathbf{F}_{\text {tabel }}$ & Kesimpulan \\
\hline $\begin{array}{c}\text { Ekperimen } \\
\text { Kontrol }\end{array}$ & $\begin{array}{c}36,565 \\
43\end{array}$ & 1,174 & 1,783 & Homogen \\
\hline
\end{tabular}

Tabel 4. Rangkuman Uji Normalitas Data Tes II

\begin{tabular}{cccccc}
\hline Data Tes II & $\mathbf{N}$ & $\boldsymbol{\alpha}$ & $\boldsymbol{X}^{\mathbf{2}}$ hitung & $\boldsymbol{x}^{\mathbf{2}}$ tabel & \multirow{2}{*}{ Kesimpulan } \\
\hline Eksperimen & 35 & 0,05 & 3,858 & 11,07 & \multirow{2}{*}{ Normal } \\
Kontrol & 34 & 0,05 & 2,709 & & \\
\hline
\end{tabular}

Keterangan: $\mathrm{N}=$ Jumlah siswa

$$
\alpha=\text { Taraf signifikansi }
$$

Tabel 5. Rangkuman Uji Homogenitas Data Tes II

\begin{tabular}{ccccc}
\hline Data Soal Tes I & Varians & F $_{\text {hitung }}$ & F tabel $_{\text {Kesimpulan }}$ & Ken \\
\hline Ekperimen & 292,138 & 1,424 & 1,783 & Homogen \\
Kontrol & 205,010 & 1,4 & & \\
\hline
\end{tabular}

Data yang diperoleh menunjukkan bahwa rata-rata data tes I dan tes II pada kelompok eksperimen adalah sebesar 71,735 dan pada kelompok kontrol adalah sebesar 49,489. Data yang diperoleh kemudian diolah menggunakan SPSS 25 untuk menunjukkan nilai signifikansi N-gain kedua kelas sampel. Nilai signifikansi diperoleh dengan uji analisis Shapiro-Wilk, dengan signifikansi 0,790 untuk kelas eksperimen dan signifikansi 0,074 untuk kelas kontrol. Rangkuman uji independen N-gain Shapiro-Wilk dapat dilihat pada Tabel 6. 
Tabel 6. Rangkuman Uji Independen N-Gain Shapiro-Wilk

\begin{tabular}{lcccc}
\hline & Kelompok Kelas & N & Sig. & Keterangan \\
\hline \multirow{2}{*}{ N-Gain (\%) } & Eksperimen & 35 & 0,790 & \multirow{2}{*}{ Normal } \\
\hline
\end{tabular}

Keterangan: $\mathrm{N}=$ Jumlah siswa

Sig. $=$ Taraf signifikansi

$\mathrm{H}_{0}=$ pemberian tuntunan penyelesaian latihan soal dalam pembelajaran langsung tidak berpengaruh terhadap pemahaman konsep perhitungan $\mathrm{pH}$ larutan penyangga pada siswa kelas XI MIPA MAN Kota Palangka Raya tahun ajaran 2018/2019.

$\mathrm{H}_{\mathrm{a}}=$ pemberian tuntunan penyelesaian latihan soal dalam pembelajaran langsung berpengaruh terhadap pemahaman konsep perhitungan $\mathrm{pH}$ larutan penyangga pada siswa kelas XI MIPA MAN Kota Palangka Raya tahun ajaran 2018/2019.

Berdasarkan perhitungan uji-t untuk data nilai tes kedua kelas sampel, diperoleh $t_{\text {hitung }}=5,383$ dan $t_{\text {tabel }}=1,667$ pada taraf signifikansi $5 \%$ dan $\mathrm{db}=\mathrm{n}_{1}$ $+\mathrm{n}_{2}-2=67$. Jika didapat $\mathrm{t}_{\text {hitung }}>\mathrm{t}_{\text {tabel }}$, maka $\mathrm{H}_{\mathrm{a}}$ diterima dan $\mathrm{H}_{0}$ ditolak. Hal tersebut menunjukkan bahwa pemberian tuntunan penyelesaian latihan soal dalam pembelajaran langsung berpengaruh terhadap pemahaman konsep perhitungan $\mathrm{pH}$ larutan penyangga asam pada siswa kelas XI MIPA MAN Kota Palangka Raya tahun ajaran 2018/2019.

Pemahaman konsep perhitungan $\mathrm{pH}$ larutan penyangga asam pada siswa kelas eksperimen setelah menggunakan latihan soal dengan tuntunan penyelesaian dan kelas kontrol setelah menggunakan latihan soal tanpa tuntunan penyelesaian, 
dapat dibuktikan dengan analisis tiap tahapan hasil jawaban siswa. Analisis perubahan pemahaman konsep siswa mengenai perhitungan $\mathrm{pH}$ larutan penyangga asam, ditelusuri dari berbagai jawaban siswa pada hasil tes I dan tes II yang dominan berdasarkan indikator yang ingin dicapai kelas eksperimen maupun kelas kontrol. Indikator pencapaian siswa antara lain: 1) menghitung $\mathrm{pH}$ larutan penyangga dari campuran asam lemah dengan garamnya, 2) menghitung $\mathrm{pH}$ larutan penyangga asam hasil pencampuran asam lemah dengan basa kuat, dan 3) menghitung $\mathrm{pH}$ larutan penyangga asam setelah penambahan sedikit asam, sedikit basa, dan pengenceran. Indikator tersebut yang menjadi penyusun 3 butir soal uraian objektif pada tes I dan tes II, yang merupakan tes pemahaman konsep.

\section{a. Perubahan Pemahaman Konsep Siswa dalam Menghitung pH Larutan Penyangga dari Campuran Asam Lemah dengan Garamnya}

Pemahaman konsep siswa dalam indikator I: menghitung $\mathrm{pH}$ larutan penyangga dari campuran asam lemah dengan garamnya, dapat dilihat dari butir soal 1 dan skor maksimalnya sebesar 2 .

Tabel 7. Perubahan Rata-rata Skor Tes I dan Tes II Kelas Eksperimen dan Kelas Kontrol pada Indikator 1

\begin{tabular}{ccc}
\hline \multirow{2}{*}{ Kelompok kelas } & \multicolumn{2}{c}{ Rata-rata Skor } \\
\cline { 2 - 3 } & Tes I & Tes II \\
\hline Eksperimen & 87,15 & 97,15 \\
Kontrol & 91,20 & 94,10 \\
\hline
\end{tabular}

Tabel 7 menunjukkan bahwa perubahan pemahaman konsep siswa yang menerima pembelajaran langsung menggunakan latihan soal dengan tuntunan penyelesaian rata-rata skornya relatif tidak berbeda dengan siswa yang menerima pembelajaran langsung menggunakan latihan soal tanpa tuntunan penyelesaian. 
Perubahan skor pemahaman konsep siswa dari tes I dan tes II, baik kelas eksperimen maupun kelas kontrol dapat dilihat pada Tabel 8.

Tabel 8. Perubahan Skor Tes I dan Tes II Kelas Eksperimen dan Kelas Kontrol pada Indikator 1

\begin{tabular}{ccccc}
\hline & \multicolumn{5}{c}{ Perubahan Skor Tes } \\
\cline { 2 - 5 } Skor & \multicolumn{2}{c}{ Tes I } & \multicolumn{2}{c}{ Tes II } \\
\cline { 2 - 5 } & $\begin{array}{c}\sum_{\text {Siswa }} \text { Kelas } \\
\text { Eksperimen }\end{array}$ & $\begin{array}{c}\sum_{\text {Siswa }} \text { Kelas } \\
\text { Kontrol }\end{array}$ & $\begin{array}{c}\sum \text { Siswa } \\
\text { Kelas } \\
\text { Eksperimen }\end{array}$ & $\begin{array}{c}\sum \text { Siswa } \\
\text { Kelas } \\
\text { Kontrol }\end{array}$ \\
\hline 0 & - & - & - & - \\
1 & 9 & 5 & 2 & 2 \\
2 & 26 & 29 & 33 & 32 \\
\hline
\end{tabular}

Pemahaman siswa terhadap butir soal 1 masih tergolong tinggi. Baik siswa kelas eksperimen maupun kelas kontrol mampu menyelesaikan dua langkah penyelesaian dengan benar. Perubahan rata-rata skor tes I dan tes II kelas eksperimen dari $87,15 \%$ meningkat menjadi $97,15 \%$. Perubahan rata-rata skor tes I dan tes II kelas kontrol dari 91,2\% menjadi 94,10\%.

\section{b. Perubahan Pemahaman Konsep Siswa dalam Menghitung pH Larutan Penyangga Asam Hasil Pencampuran Asam Lemah dan Basa \\ Kuat}

Pemahaman konsep siswa dalam indikator II: menghitung $\mathrm{pH}$ larutan penyangga asam hasil pencampuran asam lemah dengan basa kuat, dapat dilihat dari soal butir soal 2 dan skor maksimalnya sebesar 4 .

Tabel 9. Perubahan Rata-rata Skor Tes I dan Tes II Kelas Eksperimen dan Kelas Kontrol pada Indikator 2

\begin{tabular}{ccc}
\hline \multirow{2}{*}{ Kelompok kelas } & \multicolumn{2}{c}{ Rata-rata Skor } \\
\cline { 2 - 3 } & Tes I & Tes II \\
\hline Eksperimen & 58,58 & 92 \\
Kontrol & 57,35 & 85,30 \\
\hline
\end{tabular}


Tabel 9 menunjukkan bahwa pemahaman konsep siswa baik kelas eksperimen maupun kelas kontrol mengalami peningkatan. Rata-rata skor kelas eksperimen lebih tinggi dibanding dengan rata-rata skor kelas kontrol.

Tabel 10. Perubahan Tes I dan Tes II Kelas Eksperimen dan Kelas Kontrol pada Indikator 2

\begin{tabular}{ccccc}
\hline & \multicolumn{5}{c}{ Perubahan Skor Tes } \\
\cline { 2 - 5 } Skor & \multicolumn{2}{c}{ Tes I } & \multicolumn{2}{c}{ Tes II } \\
\cline { 2 - 5 } & $\begin{array}{c}\sum \text { Siswa } \\
\text { Kelas } \\
\text { Eksperimen }\end{array}$ & $\begin{array}{c}\sum_{\text {Siswa }} \text { Kelas } \\
\text { Kontrol }\end{array}$ & $\begin{array}{c}\sum \text { Siswa } \\
\text { Kelas } \\
\text { Eksperimen }\end{array}$ & $\begin{array}{c}\sum \text { Siswa } \\
\text { Kelas } \\
\text { Kontrol }\end{array}$ \\
\hline 0 & 1 & - & - & - \\
1 & 5 & 8 & - & - \\
2 & 17 & 16 & 1 & 4 \\
3 & 5 & 2 & 9 & 12 \\
4 & 7 & 8 & 25 & 18 \\
\hline
\end{tabular}

Pemahaman siswa terhadap butir soal 2 masih tergolong tinggi. Baik siswa kelas eksperimen maupun kelas kontrol mampu menyelesaikan empat langkah penyelesaian dengan benar. Perubahan rata-rata skor tes I dan tes II kelas eksperimen dari 58,57\% meningkat menjadi $92 \%$. Perubahan rata-rata skor tes I dan tes II kelas kontrol dari 57,35\% menjadi $85,3 \%$. Pada konsep ini tuntunan penyelesaian sangat berpengaruh terhadap pemahaman konsep siswa kelompok bawah kelas eksperimen.

\section{c. Perubahan Pemahaman Konsep Siswa dalam Menghitung pH Larutan Penyangga Asam Setelah Penambahan Sedikit Asam, Sedikit Basa, dan Pengenceran}

Pemahaman siswa dalam indikator III: menghitung $\mathrm{pH}$ larutan penyangga asam setelah penambahan sedikit asam, sedikit basa, dan pengenceran dilihat dari butir soal 3 dengan skor maksimal 16. Deskripsi pemahaman konsep siswa dan skor jawaban siswa pada indikator 3 ini dibagi menjadi 4 bagian, pada masing- 
masing bagian mempunyai skor yang berbeda. Bagian 1 menghitung $\mathrm{pH}$ larutan penyangga awal (lima langkah penyelesaian), bagian 2 menghitung $\mathrm{pH}$ larutan penyangga asam setelah penambahan sedikit asam (empat langkah penyelesaian), dan bagian 3 menghitung $\mathrm{pH}$ larutan penyangga asam setelah penambahan sedikit basa (empat langkah penyelesaian), serta bagian 4 menghitung $\mathrm{pH}$ larutan penyangga asam setelah pengenceran (tiga langkah penyelesaian).

Tabel 11. Perubahan Rata-rata Skor Tes I ke Tes II Kelas Eksperimen dan Kelas Kontrol pada Indikator 3

\begin{tabular}{ccc}
\hline \multirow{2}{*}{ Kelompok Kelas } & \multicolumn{2}{c}{ Rata-rata Skor } \\
\cline { 2 - 3 } & Tes I & Tes II \\
\hline Eksperimen & 4,29 & 71,96 \\
Kontrol & 3,67 & 49,475 \\
\hline
\end{tabular}

Tabel 11 menunjukkan perubahan rata-rata skor tes I ke tes II yang membuktikan bahwa pemahaman konsep siswa yang menerima pembelajaran langsung menggunakan latihan soal dengan tuntunan penyelesaian lebih tinggi rata-rata skornya daripada siswa yang menerima pembelajaran langsung menggunakan latihan soal tanpa tuntunan penyelesaian. Kebanyakan siswa menganggap mudah butir soal nomor 3 yang nyatanya mempunyai skor yang paling besar dibanding skor soal butir nomor 1 maupun 2 .

Tabel 12. Perubahan Skor Tes I dan Tes II Kelas Eksperimen dan Kelas Kontrol pada Indikator 3 Bagian 1

\begin{tabular}{|c|c|c|c|c|}
\hline \multirow[b]{3}{*}{ Skor } & \multicolumn{4}{|c|}{ Perubahan Skor Tes } \\
\hline & \multicolumn{2}{|c|}{ Tes I } & \multicolumn{2}{|c|}{ Tes II } \\
\hline & $\begin{array}{c}\Sigma \text { Siswa } \\
\text { Kelas } \\
\text { Eksperimen }\end{array}$ & $\begin{array}{c}\Sigma \text { Siswa } \\
\text { Kelas } \\
\text { Kontrol }\end{array}$ & $\begin{array}{c}\Sigma \text { Siswa } \\
\text { Kelas } \\
\text { Eksperimen }\end{array}$ & $\begin{array}{c}\text { Siswa } \\
\text { Kelas } \\
\text { Kontrol }\end{array}$ \\
\hline 0 & 17 & 9 & - & - \\
\hline 1 & 12 & 10 & - & 1 \\
\hline 2 & 6 & 5 & - & 5 \\
\hline 3 & - & - & 4 & 6 \\
\hline 4 & - & - & 11 & 17 \\
\hline 5 & - & - & 20 & 5 \\
\hline
\end{tabular}


Tabel 13. Perubahan Skor Tes I dan Tes II Kelas Eksperimen dan Kelas Kontrol pada Indikator 3 bagian 2

\begin{tabular}{ccccc}
\hline & \multicolumn{4}{c}{ Perubahan Skor Tes } \\
\cline { 2 - 5 } Skor & \multicolumn{2}{c}{ Tes I } & \multicolumn{2}{c}{ Tes II } \\
\cline { 2 - 5 } & $\begin{array}{c}\boldsymbol{\Sigma} \text { Siswa } \\
\text { Kelas } \\
\text { Eksperimen }\end{array}$ & $\begin{array}{c}\boldsymbol{\Sigma} \text { Siswa } \\
\text { Kelas } \\
\text { Kontrol }\end{array}$ & $\begin{array}{c}\boldsymbol{\Sigma} \text { Siswa } \\
\text { Kelas } \\
\text { Eksperimen }\end{array}$ & $\begin{array}{c}\boldsymbol{\Sigma} \text { Siswa } \\
\text { Kelas } \\
\text { Kontrol }\end{array}$ \\
\hline 0 & 35 & 34 & - & 4 \\
1 & - & - & 2 & 4 \\
2 & - & - & 12 & 19 \\
3 & - & - & 4 & 3 \\
4 & - & - & 17 & 4 \\
\hline
\end{tabular}

Tabel 14. Perubahan Skor Tes I dan Tes II Kelas Eksperimen dan Kelas Kontrol pada Indikator 3 bagian 3

\begin{tabular}{ccccc}
\hline & \multicolumn{4}{c}{ Perubahan Skor Tes } \\
\cline { 2 - 5 } Skor & \multicolumn{2}{c}{ Tes I } & \multicolumn{2}{c}{ Tes II } \\
\cline { 2 - 5 } & $\begin{array}{c}\boldsymbol{\Sigma} \text { Siswa } \\
\text { Kelas } \\
\text { Eksperimen }\end{array}$ & $\begin{array}{c}\boldsymbol{\Sigma} \text { Siswa } \\
\text { Kelas } \\
\text { Kontrol }\end{array}$ & $\begin{array}{c}\boldsymbol{\Sigma} \text { Siswa } \\
\text { Kelas } \\
\text { Eksperimen }\end{array}$ & $\begin{array}{c}\boldsymbol{\Sigma} \text { Siswa } \\
\text { Kelas } \\
\text { Kontrol }\end{array}$ \\
\hline 0 & 35 & 34 & 1 & 7 \\
1 & - & - & 5 & 5 \\
2 & - & - & 16 & 18 \\
3 & - & - & 4 & 3 \\
4 & - & - & 9 & 1 \\
\hline
\end{tabular}

Tabel 15. Perubahan Skor Tes I dan Tes II Kelas Eksperimen dan Kelas Kontrol pada Indikator 3 bagian 4

\begin{tabular}{ccccc}
\hline & \multicolumn{4}{c}{ Perubahan Skor Tes } \\
\cline { 2 - 5 } Skor & \multicolumn{2}{c}{ Tes I } & \multicolumn{2}{c}{ Tes II } \\
\cline { 2 - 5 } & $\begin{array}{c}\boldsymbol{\Sigma} \text { Siswa } \\
\text { Kelas } \\
\text { Eksperimen }\end{array}$ & $\begin{array}{c}\boldsymbol{\Sigma} \text { Siswa } \\
\text { Kelas } \\
\text { Kontrol }\end{array}$ & $\begin{array}{c}\boldsymbol{\Sigma} \text { Siswa } \\
\text { Kelas } \\
\text { Eksperimen }\end{array}$ & $\begin{array}{c}\boldsymbol{\Sigma} \text { Siswa } \\
\text { Kelas } \\
\text { Kontrol }\end{array}$ \\
\hline 0 & 35 & 34 & 10 & 19 \\
1 & - & - & 5 & 7 \\
2 & - & - & 9 & 5 \\
3 & - & - & 11 & 3 \\
\hline
\end{tabular}

Pemahaman siswa terhadap butir soal 3 masih tergolong rendah. Baik siswa kelas eksperimen maupun kelas kontrol masih belum mampu menyelesaikan 16 langkah penyelesaian dengan benar. Perubahan rata-rata skor 
tes I dan tes II kelas eksperimen dari 4,29\% meningkat menjadi $71,96 \%$. Perubahan rata-rata skor tes I dan tes II kelas kontrol dari 3,67\% menjadi 49,45\%. Konsep butir soal nomor 3 ini mampu meningkatkan kemampuan siswa dalam memahami konsep perhitungan $\mathrm{pH}$ larutan penyangga asam setelah penambahan sedikit asam, basa, dan pengenceran. Siswa dituntut mampu menyelesaikan soal sesuai dengan banyaknya langkah penyelesaian.

Tuntunan yang diberikan meningkatkan pemahaman konsep siswa, baik kelas atas maupun kelas bawah kelas eksperimen. Selain itu peningkatan juga terjadi pada kelas kontrol yang dipengaruhi oleh adanya diskusi yang dilakukan saat pemberian latihan soal tanpa tuntunan penyelesaian.

\section{Simpulan}

Hasil uji statistik menggunakan uji-t menunjukkan bahwa $t_{\text {hitung }}(5,383)$ lebih besar dari $t_{\text {tabel }}(1,67)$ pada taraf signifikan $5 \%$, artinya pemberian tuntunan penyelesaian latihan soal berpengaruh terhadap pemahaman konsep perhitungan pH larutan penyangga asam pada siswa kelas XI MIPA MAN Kota Palangka Raya Tahun Ajaran 2018/2019. Rata-rata nilai tes II kelas eksperimen $(77,992)$ lebih tinggi dari kelas kontrol $(60,561)$.

Berdasarkan hasil penelitian, disarankan bahwa pembelajaran langsung menggunakan latihan soal dengan tuntunan penyelesaian dalam pembelajaran kimia dapat dijadikan salah satu alternatif pilihan untuk meningkatkan pemahaman konsep siswa. Namun, guru juga harus menyesuaikan dengan materi pelajaran, yaitu materi yang berupa pengetahuan prosedural. 


\section{Daftar Referensi}

Achmad, H. 1996. Penentuan Belajar Kimia Dasar Kimia Larutan. Bandung: Penerbit PT. Citra Aditya Bakti.

Aini, Y. N. 2013. Kesulitan Siswa Kelas XI IPA SMA Negeri 4 Palangka Raya Tahun Ajaran 2012/2013 dalam Memahami Konsep Larutan Penyangga. Skripsi sarjana, tidak diterbitkan, Universitas Palangka Raya.

Ambarwati, R. 2018. Analisis Kesulitan Belajar Siswa SMA pada Materi Larutan Penyangga menggunakan Three Tier Multiple Choice Diagnostic Instrument. Skripsi sarjana, diterbitkan, Universitas Islam Negeri Syarif Hidayatullah Jakarta.

Dahar, R. W. 2006. Teori-teori Belajar dan Pembelajaran. Bandung: PT. Gelora Aksara Pratama.

Djamarah, S., \& Zain, A. 2010. Strategi Belajar Mengajar. Jakarta: Rineka Cipta. Hidayati, L. 2018. Perbedaan Pengaruh Ion Senama dan pH Larutan Terhadap Kelarutan Hasil Pembelajaran Langsung menggunakan LKS Latihan Soal Terstruktur pada Siswa Kelas XI MIPA MAN Kota Palangka Raya Tahun Ajaran 2018/2019. Skripsi sarjana, tidak diterbitkan, Universitas Palangka Raya.

Indahsari, E. N. 2018. Perbedaan Pemahaman Konsep Tata Nama Senyawa Alkana Hasil Pembelajaran Langsung Menggunakan LKS-Latihan Soal Terstruktur dan LKS-Latihan Soal pada Siswa Kelas XI MIPA SMA Negeri 4 Palangka Raya Tahun Ajaran 2018/2019. Skripsi sarjana, tidak diterbitkan, Universitas Palangka Raya. 
Isnaini, dkk. 2016. Pemahaman Konsep Materi Larutan Penyangga Menggunakan Two Tier Multiple Choice Diagnostic Instrument di SMA. Artikel, diterbitkan, Universitas Tanjungpura Pontianak.

Khotiro, N. B. 2016. Pembelajaran Model Missouri Mathematichs Project untuk Meningkatkan Pemahaman Konsep Matematika Siswa pada Pokok Bahasan Prisma dan Limas di SMP Muhammadiyah 2 Purwokerto. Skripsi Sarjana, diterbitkan, Universitas Muhammadiyah Purwokerto. dari https://repository.ump.ac.id/924/daftar\%20_binta\%20nur\%20khotiro_Mat ematika\%2716.pdf Diakses pada 2 Februari 2019.

Kountur, R. 2009. Metode Penelitian. Jakarta: Buana Printing.

Majid, A. 2013. Strategi Pembelajaran. Bandung: PT. Remaja Rosdakarya.

Maniring, J. 2017. Statistika Pendidikan Konsep \& Penerapannya Menggunakan Minitab dan Microsoft Excel. Yogjakarta: Penerbit ANDI.

Poerwadarminta, W.J.S. 1999. Kamus Besar Bahasa Indonesia. Jakarta: Balai Pustaka.

Qadratilah, M., dkk. 2011. Kamus Bahasa Indonesia untuk Pelajar. Jakarta: Badan Pengembangan dan Pembinaan Bahasa.

Raharjo, S. 2019. Cara Uji T Independent untuk N-gain Score dengan SPSS Lengkap dari http://youtube.be/rc0U0o7_uy8 Diakses Pada 27 Mei 2019.

Rahman, N. E. 2014. Pengaruh Penggunaan LKS Terhadap Kemampuan Pemahaman Konsep Larutan Penyangga pada Siswa Kelas XI IPA SMA Negeri 3 Palangka Raya Tahun Ajaran 2013/2014. Skripsi sarjana, tidak diterbitkan, Universitas Palangka Raya. 
Rusman. 2012. Model-model Pembelajaran Mengembangkan Profesionalisme Guru Edisi Kedua. Bandung: PT. Raja Grafindo Persada.

Sagala, S. 2003. Konsep dan Makna Pembelajaran. Bandung: Alfabeta.

Sanjaya, W. 2013. Penelitian Pendidikan: Jenis, Metode, dan Prosedur. Bandung: PT. Fajar Interpratama Mandiri.

Simatupang, N. Penerapan Metode Eksperimen Terhadap Peningkatan Hasil Belajar Kimia Siswa pada Materi Laju Reaksi. Jurnal Pendidikan Kimia Vol. 9, No. 2, Agustus 2017 p.318-322.

Suhana, C. 2014. Konsep Strategi Pembelajaran Edisi Revisi. Bandung: Reflika Aditama.

Sugiyono. 2010. Metode penelitian pendidikan (pendekatan kuantitatif, kualitatif, dan $R \& D)$. Bandung: Alfabeta.

Yulita. 2012. Pengaruh Penggunaan LKS Terstruktur terhadap Pemahaman Konsep Rumus Empiris dan Rumus Molekul pada Siswa Kelas X-I SMA Isen Mulang Palangka Raya Tahun Ajaran 2011/2012. Skripsi sarjana, tidak diterbitkan, Universitas Palangka Raya.

Widodo, A. 2005. Taksonomi Tujuan Pembelajaran. Didaktis. 4(2), 61-69. 